\title{
Reflection on Higher Education under the Influence of the Market Economy
}

\author{
H.M. ZHAO \\ Teaching and Research Institute of Foreign Languages, Bohai university, Jinzhou 121013, China
}

\begin{abstract}
The rapid development of market economy has brought huge economic wealth to current society, also brought pragmatism and utilitarianism, which have seriously eroded the development of higher education. Reflections on the functions and purposes of higher education greatly benefit to the development of university. Starting from the connotation of higher education, the author analyzes the problems of higher education, and puts forward three basic functions of higher education, namely "perfection" talent cultivation, the pursuit of truth and inheritance of culture.
\end{abstract}

KEYWORD: Liberal Education; Idea of University; Social Services; Cultural Inherence

\section{INTRODUCTION}

With the deepening of reform and opening up and the coming of economic society, higher education has been developed for one hundred years. Higher education has provided our society a large number of talents. While cheering for the achievement of higher education in China, we also need to think about the problems existing in Chinese higher education. In the market economy, a variety of utilitarianism and pragmatism has been eroding the higher education. The former "ivory tower" now seems like a dream of yesterday. We always keep asking ourselves the questions: "What is the purpose of higher education? What problems does the current higher education have? How does the higher education better fulfill its mission?" In fact, all the educators in the world have long been reflecting on the problems of higher education in current society. In the $350^{\text {th }}$ anniversary celebration, President Derek Bok anxiously said: "If one characteristic of Harvard has been persisted for 350 years, that is, we have always uneasy feeling. Although there is no reason to worry about it from the outside situation, we always do." Through the speech of Bok, he worried about how Harvard did it best in social services, administration and academic freedom, so as to avoid falling in the feeling of self satisfaction. Currently, the crisis encountered by higher education has worried many educators. Therefore, it is beneficial to the development of higher education that we explore the mission of higher education and analyze the problems faced by it and find out the solution of it.

\section{REFLECTION ON THE CONNOTATION OF HIGHER EDUCATION}

As the organization of higher education activities, the function and idea of university have experienced three major changes since the establishment. The function of university changes from the teaching to both teaching and research proposed by Humboldt, then to the functions of scientific research, teaching and social service. Today, under the influence of market economy, the education of domestic universities has been impacted greatly by the external factors. Therefore, it is necessary to make a thorough discussion on the connotation of higher education[1].

(1) Is it the professional education? At present, many domestic universities lost themselves in the complicated market economy. Many universities always stress the appropriateness of major. In order to improve the rate of students' employment, new majors are set up for special enterprises. When the students enter the university, they begin to learn the major courses besides English and politics. The advantage is plausible because the students can quickly integrate into the workplace, which lifts the rate of employment. But from the goal of higher education, this measure is rather superficial. The main purpose of higher education is to cultivate the rational thinking ability of students and the ability of actively learning the knowledge, but not to train students professionally. In ancient, Aristotle and Plato advocated the rational thinking and being free and wise man. Kant also said that the purpose of 
people is personhood and people must be commanded by rationality as soon as possible. Therefore, people begin to pursuit the philosophy and universal truth. The modern European university came into being with the spirit of free education, namely, it cultivates the rational thinking ability and makes the students form philosophical habits. The goal of rational training and university education is not the knowledge, but the idea or rationality based on the knowledge. Therefore, the substantial education of university is the educational activity endued with the spirit of free education, and is the education that fully cultivates the intellect and morality of students[2]. In the guidance of the spirit of free education, the undergraduate education of the world famous universities is most general education. Namely, the literal arts students are required to learn the knowledge of natural science while the science students also learn the courses of philosophy, history, archaeology, aesthetics etc. Nietzsche once fiercely criticized the education of utilitarianism. He believes that true education is a little feet fairy while the socalled education for making a living is just a servant girl, or a wise maid in charge of livelihood, income and demand. If any school education sets its goal as the way of making a living or acquiring a position, it is not a real education, but the manual of guiding people to struggle for existence. The according institutions are some institutions of dealing with the livelihood, but not the real educational institutions [3].

(2) Is higher education for the purpose of economic development? According to the viewpoint of Marx, the human beings need not only the life of material but also the spiritual life. The universities play the roles of producer and disseminator of knowledge and culture. Throughout the history of university development, the universities do not aim at the demand of economy since the initial establishment. Moreover, the condition of economy does not determine the level of university. For example, although the European economy in middle ages is far behind the Chinese economy, the first university came into being in Europe. Therefore, it is incorrect to make the university serve the economy.

Today, in the economic society with efficiency and effectiveness, university inevitably suffers from the impact of secular viewpoints and interests. The utilitarian measures have been taken for the domestic and international universities. The role of promoting economy is emphasized too much while the most basic function of university is lost. That is, university loses its functions of cultural inheritance and creation. University is no long the holy land to cultivate the free people and pursue the knowledge, truth and freedom, but the occupation training place to teach people to make a living. In the history, there is the example that utilities are emphasized too much to lead to cultural barren and national overturn.
Hutchins once said "Roman is a great nation, but they are too pragmatic, which leads to the thinking barren and little of accomplishment and is criticized by people." Is the development of university independent of economy in the society? The answer is of course not. Today, the rapid development of information technology promotes the transition of social economy. The social economy now depends mainly on knowledge. It is a typical knowledge economy era. The core of knowledge economy is the knowledge and technology as well as the according personnel. For example, in the rank of world wealth, Bill Gates was rated as the world's richest man. His empire of Microsoft arises from the computer software. As the base of research and personnel training, it is no doubt that university has the role to promote the development of economy. University directly provides the core technology and science as well as the according personnel for the development of economy. Therefore, the activities of university education and research are the production of knowledge economy. Thus university is neither the supporting role nor the servant of economic society, but the master that directly affects the development of economy. Chang-lin Tien, president of Berkeley in California, USA, once said: "science parks must be led by higher education. The most successful example is the Silicon Valley in America, in which Stanford and Berkeley universities locate. Now the most successful biotechnology center locates in San Francisco because the two most famous universities locate in the city. But it is wrong to think the economic promotion as the goal of university. The main activities of university are cultural ones and its action on economy is performed through its cultural function. It is wrong that one abandons the cultural function of university while emphasizes the economic promotion. It is also the perversion of university that one abandons the cultural function while emphasizes the professional counterparts or employment.

(3) Does the higher education explore the profound knowledge? Profound knowledge is the knowledge that stays in the boundary between the known and unknown. [4]Because it is too abstruse and mysterious, the ordinary people can not grasp it. Profound knowledge is not the same in different era. Today, the calculus of advanced mathematics is much easier for the college students. However, it definitely belongs to the profound knowledge in the era of Newton. Similarly, the Newton mechanics is much easier for the students of junior school while it is much abstruse in the era of Newton. Therefore, profound knowledge is always relative to the period in which it emerges. But the cultural function of university determines that university is directly engaged in exploring the profound knowledge. The so-called profound knowledge is always relative to those we have already known. Therefore, the 
profound knowledge means that the according subject is just in the researching stage and its applying prospect is not obvious, and some do not even have the concrete applying prospect. In the beginning of the establishment of Newton mechanics, its role is limited to the theoretical research and the applying prospect is not clear. But our world is really changed since the establishment of Newton mechanics. Even 300 years later, we still use the Newton's formula to study the orbital of flying satellite and spaceship in space. But Newton did not intend to serve the astronavigation by establishing his mechanics. Therefore, in the beginning of research, a profound knowledge is not utilitarian. It is the pure knowledge. From the Maslow' theory of hierarchy of needs, it belongs to the higher levels of demand of free people, namely, self-value pursuit and the pursuit of science and truth. And the purpose of higher education is to meet the comprehensive needs of people and cultivate the free man.

\section{REDIRECTION OF HIGHER EDUCATION}

When one looks at university without the secular perspectives, he can grasp the overall characteristics of university. The university is the organization that is devoted to the development of knowledge and solves various problems and cultivates the talent and tries to remain a high level. University is also the paradise of scientists, but not the thermometer that reacts to the social fashion immediately. University must give something to society. They may not be the things the society wants, but the need of society. To sum up, university has three functions: the cultivation of talent, the pursuit of knowledge and culture output.

(1) It is the place to develop comprehensively the morality and intelligence of students. The truth of university lies in illustrating virtue and striving to excel until reaching perfection. The essence of university is to cultivate a person to be a gentleman and cultivate the students to have noble morality and quality. It is not just a place to impart the knowledge. Newman, a modern education in British, believes that the mission of university is to provide both the liberal education and the mental training. It cultivates the gentlemen who have knowledge, wisdom and ideal and culture. Hutchins once believes that the primary purpose of education is to make students to know what is good, namely the principles of the world. Because of the various levels of value, the task of education is to help people understand the value and establish the value system. Therefore, university is not only the place to teach the knowledge, but also the site to construct the morality and value. The philosophy of Marx holds that people not only have the social attributes, but also have self-awareness and initiatives. The purpose of higher education aims to improve the selfconsciousness and initiatives of students. It sublimates the personality and integrates the morality and makes the reasons clear, so that people can exert the characteristics of human being, namely the initiatives and self-consciousness. As the place of training talent, the primary purpose of university is to develop the morality and values of students, improve the moral system and integrate the judgment ability of students. Therefore, the university should be the place to perfect the personality and develop oneself [5].

(2) It is the holy land to pursue the knowledge and truth. From the Maslow's theory of hierarchy of needs, people first want to meet their most basic physiological needs. After that, the needs will gradually transit to the high level of demand. At the highest level, people want to satisfy the needs of self realization, namely, the pursuit for goodness, truth and beauty. This pursuit is not affected by the utilitarian. It is the pure activity for people to realize self value. In the beginning, the university is established to satisfy the higher level demand of people. This demand has no necessary connection with the conditions of economy. Even in poor condition, people have the desire to pursue the truth and knowledge. Therefore, as the place of training senior intellectuals, university should satisfy the students' pursuit to truth and knowledge. It should not only aim at the purpose of professions and application. At the same time, the pursuit to profound knowledge is very important to promote the future science and technology. In 1873, when Maxwell finished his electromagnetic theory, it is just the profound knowledge and has nothing to do with application. In 1888, Hertz demonstrated the existence of electromagnetic waves by experiments. In this decade, the study of Maxwell is just the profound knowledge. But the later development of technology shows that the theory of Maxwell paves the way to the modern electronic industrial civilization. Even Maxwell himself did not expect it. Therefore, the pursuit of pure knowledge is the noble behavior of human being that is not influenced by the utilitarianism. It is the pursuit to the pure knowledge that promotes the development of society. The development of science and technology are not conceived and predicted by people. It arises from pursuing to pure knowledge and truth. Therefore, university should abandon the various utilitarianism and secular practices and encourage the teacher and students to pursue the pure knowledge and truth.

(3) It is the source of cultural inheritance and innovation. Culture is the history brand of nation and is the precipitation of national spirit in the history. Culture has an great impact on people. The advanced culture can inspire people, educate people and cultivate the world outlook and values of people. When we look forward to the future, we also review 
the history. The cultural learning and inheritance can help us to understand the origin and customs of ourselves, understand the values and morality of the nation, so as to better establish their own value system. The university is the best center place to present the culture of nation. All the famous universities attach the importance to cultural heritage. After World War II, Harvard University emphasizes that the main task of education is to integrate the human wealth of knowledge and impart common values, and cultivate the students to be responsible for the society. During the period of his president, Hutchins has launched the Chicago plan, which asks the students to read the classics. This makes the students inherit the culture. A university can not develop its soft power without the cultural inherence. Cultural inherence plays an important role in the construction of campus humanistic spirit and unique style. In addition, university is the place in which top intellectuals live and is the gathering place of national wisdom and knowledge. University realizes the cultural output and social improvement by outputting the talents with perfect morality and value. Through criticizing the social culture, university realize the criticism of social culture and redirection. Therefore, university should fully exert its function of culture inheritance and innovation, so as to realize the role of radiation and criticism to social culture.

\section{CONCLUSION}

The development of market economy greatly impacts the functions of university. It is very important how to correctly evaluate the purpose of higher education. As the center of liberal arts education, university should cultivate the personnel with perfect goodness, truth and beauty, and resist eroding from social utilitarianism by persisting in its function of cultural inherence.

\section{REFERENCES}

[1] Zhang, C. T., 2010, Introduction of higher education, People's education Press. (In Chinese).

[2] Newman, J. H. C., 1907, the idea of a university, Longmans: London.

[3] Nietzsche, F. W., on the future of our educational institutions, Yilin Press: Nanjing. 6: 2012. (In Chinese).

[4] Brubacher, J. S., 1977, on the philosophy of higher education, San Francisco: Jossey-Bass, Inc.

[5] Smith, R. N., the Harvard Century. Simon and Schuster, 29:1986. 